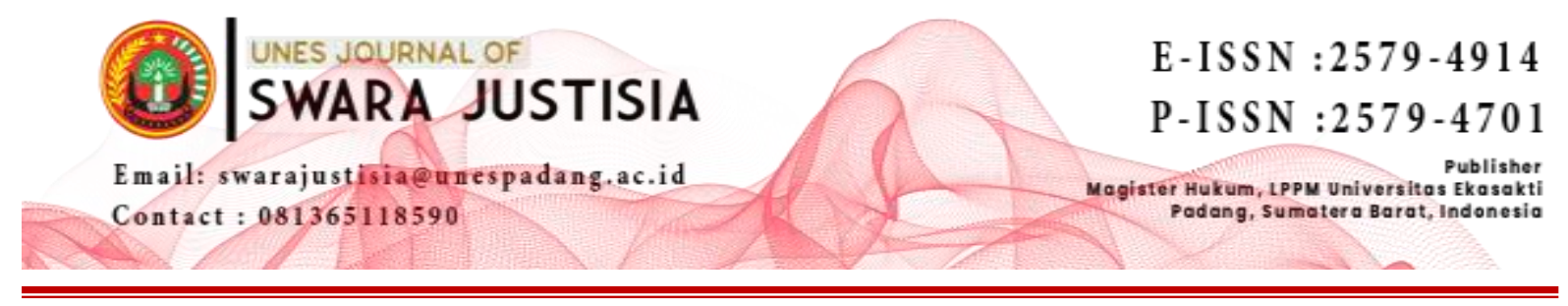

\title{
EKSISTENSI ADVOKAT SEBAGAI PENEGAK HUKUM DALAM PROSES PERADILAN PIDANA DITINJAU DARI PASAL 56 KITAB UNDANG-UNDANG HUKUM ACARA PIDANA
}

\author{
Alam Suryo Laksono \\ Program Magister Ilmu Hukum,Universitas Ekasakti, Padang \\ Email: alamsuryolaksono@gmail.com
}

\begin{abstract}
As already stated in Article 5 of Law Number 18 of 2003 concerning Advocates, advocates are law enforcers. However, in practice, it is limited to the use of rights by suspects and granted by investigators when there is a criminal incident as regulated in Article 56 of the Criminal Procedure Code. This makes the limitation of the advocate profession which is one of the doors in providing access to justice for the community, especially in the criminal justice process. discussion and analysis, it is concluded, firstly, the existence of advocates as law enforcers in the criminal justice process in terms of Article 56 of the Criminal Procedure Code is limited to criminal threats in a criminal act and depends on the legal understanding of the investigator in granting full rights to the suspect since the start of the inspection process. So that the existence of advocates as law enforcers will have an effect on the judicial process which is limited by the form of criminal acts and criminal threats as well as subjects at every level of examination. Second, the implication of Article 56 of the Criminal Procedure Code on the existence of advocates as law enforcers in the criminal justice process is the limited role of advocates in the judicial process, so that they cannot be present in every criminal case and the role of advocates is not involved since the beginning of the judicial process, resulting in the growth of the practice of network building in order to get a role in a criminal justice process that can injure the meaning of officium nobile attached to an advocate.
\end{abstract}

Keywords: Existence of Advocates, Law Enforcement, Criminal Justice

\begin{abstract}
ABSTRAK
Sebagaimana telah disebutkan dalam Pasal 5 Undang-undang Nomor 18 Tahun 2003 tentang Advokat bahwa advokat adalah penegak hukum. Namun prakteknya, sebatas dipergunakannya hak oleh tersangka dan diberikan oleh penyidik manakala terdapat peristiwa pidana yang diatur dalam Pasal 56 Kitab Undang-Undang Hukum Acara Pidana. Hal ini menjadikan limitasi atas profesi advokat yang merupakan salah satu pintu dalam memberikan akses terhadap keadilan bagi masyarakat khususnya dalam proses peradilan pidana. pembahasan dan analisis maka disimpulkan, pertama Eksistensi advokat sebagai penegak hukum dalam proses peradilan pidana ditinjau dari Pasal 56 Kitab Undang-Undang Hukum Acara Pidana terbatas pada ancaman pidana dalam suatu tindak pidana dan tergantung pada pemahaman hukum yang dimiliki penyidik dalam memberikan hak seutuhnya kepada
\end{abstract}


tersangka sejak awal dimulainya proses pemeriksaan. Sehingga eksistensi advokat sebagai penegak hukum akan berpengaruh dalam proses peradilan yang dibatasi oleh bentuk tindak pidana dan ancaman pidana serta subjek pada setiap tingkatan pemeriksaan. Kedua, Implikasi Pasal 56 Kitab Undang-Undang Hukum Acara Pidana terhadap eksistensi advokat sebagai penegak hukum dalam proses peradilan pidana adalah terbatasinya peran advokat dalam proses peradilan, sehingga tidak dapat hadir pada setiap perkara pidana dan peran advokat tidak dilibatkan sejak awal dimulainya proses peradilan sehingga mengakibatkan tumbuhnya praktek bina jaringan guna mendapatkan peran dalam suatu proses peradilan pidana yang dapat mencederai makna officium nobile yang melekat pada diri seorang advokat.

Kata Kunci: Eksistensi Advokat, Penegak Hukum, Peradilan Pidana

\section{PENDAHULUAN}

Mengacu pada Pasal 1 Ayat (3) Undang-undang Dasar Negara Republik Indonesia Tahun 1945, menegaskan bahwa Indonesia adalah negara hukum. Manifestasi dari Negara hukum (rechtstaat), salah satunya harus ada perlakuan yang sama bagi setiap orang dihadapan hukum. Asas persamaan dihadapan hukum equality before the law, merupakan asas dimana terdapatnya suatu kesetaraan dalam hukum pada setiap individu tanpa ada suatu pengecualian. Penegasan asas tersebut, telah dituangkan dalam Pasal 27 Ayat (1) Undangundang Dasar Negara Republik Indonesia Tahun 1945, yang menyatakan bahwa segala warga negara bersamaan kedudukannya didalam hukum dan pemerintahan dan wajib menjunjung hukum dan pemerintahan itu dengan tidak ada kecualinya.

Perlakuan sama dihadapan hukum tersebut harus berlaku bagi setiap orang bukan sekedar warga negara, sebagaimana disebutkan dalam Pasal 28 huruf (d) Undang-Undang Dasar Negara Republik Indonesia Tahun 1945, yang menyebutkan bahwa setiap orang berhak atas pengakuan, jaminan, perlindungan, dan kepastian hukum yang adil serta perlakuan yang sama dihadapan hukum.

Selanjutnya dalam Pasal 16 Kovenan Internasional tentang Hak-Hak Sipil dan Politik, International Covenant on Civil and Political Rights (ICCPR) yang ditandatangani dan disepakati di New York 19 Desember 1966, disebutkan bahwa: Everyone shall have the right to recognition everywhere as a person before the law. (Setiap orang berhak atas pengakuan di mana pun sebagai pribadi di hadapan hukum).

Selanjutnya dalam Pasal 26 Kovenan Internasional tentang Hak-Hak Sipil dan Politik (ICCPR), juga menyebutkan bahwa:

All persons are equal before the law and are entitled without any discrimination to the equal protection of the law. In this respect, the law shall prohibit any discrimination and guarantee to all persons equal and effective protection against discrimination on any ground such as race, colour, sex, language, religion, political or other opinion, national or social origin, property, birth or other status.

(Semua orang sama di depan hukum dan berhak atas kesetaraan tanpa diskriminasi perlindungan hukum. Dalam hal ini, hukum akan melarang diskriminasi dan jaminan apa pun bagi semua perlindungan yang setara dan efektif terhadap diskriminasi atas dasar apa pun seperti ras, warna kulit, jenis kelamin, bahasa, agama, politik atau pendapat lain, asal kebangsaan atau sosial, properti, kelahiran atau lainnya status). 
Kesamaan di hadapan hukum berarti setiap warga negara harus diperlakukan adil oleh aparat penegak hukum dan pemerintah. Maka setiap aparat penegak hukum terikat secara konstitusional dengan nilai keadilan yang harus diwujudkan dalam praktik. Salah satu praktek mewujudkan asas persamaan dihadapan hukum, ialah pada proses peradilan pidana. Didalam proses peradilan pidana terdapat aspek penegakan hukum yang berlandaskan asas persamaan dihadapan atau biasa disebut dengan equality before the law. ${ }^{1}$

\section{METODE PENELITIAN}

Spesifikasi penelitian adalah deskriptif analitis, dengan metode pendekatan yuridis normative didukung oleh yuridis empiris. Jenis data yang digunakan adalah data sekunder. Data sekunder diperoleh dari studi dokumen dan studi kepustakaan. Data yang diperoleh kemudian dianalisa secara kualitatif.

\section{PEMBAHASAN}

\section{A. Eksistensi Advokat Sebagai Penegak Hukum Dalam Proses Peradilan Pidana Ditinjau Dari Pasal 56 Kitab Undang-Undang Hukum Acara Pidana}

Sebelum menganilisis mengenai eksistensi advokat sebagai penegak hukum dalam proses peradilan pidana, peneliti merujuk pada proses peradilan pidana sebagaimana yang kemukakan oleh Muladi dalam bukunya yang berjudul Kapita Selekta Sistem Peradilan Pidana, bahwa peradilan pidana sebagai suatu sistem mempunyai perangkat struktur atau subsistem yang seharusnya bekerja secara koheren, koordinatif dan integratif agar dapat mencapai efesiensi dan efektivitas yang maksimal.

Nilai-nilai dasar yang menjadi prinsip dari pendekatan sistem peradilan pidana yakni menitikberatkan pada koordinasi dan sinkronisasi komponen peradilan pidana (Kepolisian, Kejaksaan, Pengadilan, Pemasyarakatan serta Advokat). Dengan menekankan adanya pengawasan dan pengendalian penggunaan kekuasaan oleh seluruh komponen yang terlibat dalam sistem peradilan pidana dan menempatkan efektivitas sistem penanggulangan kejahatan lebih utama daripada efisiensi penyelesaian perkara. Serta mengoptimalkan penggunaan hukum sebagai instrumen dalam rangka untuk memantapkan administrasi peradilan pidana.

Pada kesempatan ini peneliti akan mengetengahkan salah satu komponen yang menjadi bagian dari proses peradilan pidana. Profesi advokat secara konseptual adalah suatu pekerjaan berdasarkan keahlian dalam bidang hukum untuk melayani masyarakat secara independen dengan batasan kode etik dari komunitasnya (organisasi profesi). Kualitas keahlian secara umum biasanya ditentukan oleh masyarakat (organisasi) profesi itu sendiri atau peer group termasuk untuk mengawasinya.

Pekerjaan Advokat terentang dari penyidikan sampai pelaksanaan hukum, telah disebutkan didalam Pasal 1 huruf (a) Undang-Undang Nomor 18 Tahun 2003 tentang Advokat, bahwa advokat sebagai orang yang berprofesi memberi jasa hukum, baik di dalam maupun di luar pengadilan yang memenuhi persyaratan berdasarkan undangundang ini.

\footnotetext{
${ }^{1}$ Muladi, Kapita Selekta Sistem Peradilan Pidana, Penerbit Undip, Semarang, 1998, hlm 5 dan 7
} 
Berkelanjutan pada Pasal 5 Ayat (1) Undang-Undang Nomor 18 Tahun 2003 tentang Advokat, menyebutkan bahwa advokat berstatus sebagai penegak hukum, bebas dan mandiri yang dijamin oleh hukum dan peraturan perundang-undangan, maka kedudukan adavokat adalah setara atau sederajat dengan aparat penegak hukum lainnya (Polisi, Jaksa, Hakim).

Terbitnya Undang-Undang Nomor 18 Tahun 2003 tentang Advokat, memberikan legalitas kepada advokat untuk memberikan bantuan hukumnya kepada masyarakat, baik dalam bentuk litigasi maupun non litigasi. Undang-Undang Nomor 18 Tahun 2003 tentang Advokat, menjadi pemicu untuk membuktikan eksistensi advokat dalam peran serta penegakan hukum dan penyadaran hukum bagi masyarakat.

Dalam proses peradilan pidana di Indonesia, terdapat advokat sebagai penegak hukum dimana diatur dalam Pasal 5 Ayat (1) Undang-Undang Nomor 18 Tahun 2003 tentang Advokat, yang menyatakan advokat berstatus sebagai penegak hukum, bebas dan mandiri yang dijamin oleh hukum dan peraturan perundang-undangan. Maka dalam membahas dan menganalisis eksistensi advokat sebagai penegak hukum dalam proses peradilan pidana, peneliti memulai dengan teori yang digunakan dalam penelitian ini yaitu teori penegakan hukum.

Tolak ukur eksistensi advokat ditinjau dari teori penegakan hukum yang diketengahkan oleh Lawrence Meir Friedman, bahwa berhasil atau tidaknya penegakan hukum bergantung pada substansi hukum, struktur hukum dan budaya hukum. Dalam hal ini advokat secara normatif disebut sebagai penegak hukum oleh Undang-Undang Nomor 18 Tahun 2003 tentang Advokat, sehingga eksistensinya diukur pada keberhasilan advokat dalam melaksanakan tugas dan kewenangannya menurut UndangUndang, cara bertindak advokat (struktur hukum) dan sudut pandang budaya hukum di masyarakat terkait keberadaan advokat.

Maka eksistensi advokat ditinjau dari teori penegakan hukum, dapat dikatakan belum maksimal dimana terdapat argumentasi berbeda antar penegak hukum yang diakui oleh undang-undang di Indonesia, sebut saja polisi, jaksa, hakim dan lembaga pemasyarakatan. Dari ke empat elemen penegak hukum tersebut, maka advokat diposisikan pihak luar yang mana tidak memiliki keterkaitan secara sistem peradilan pidana yang mana diatur oleh KUHAP.

Didalam KUHAP, kedudukan advokat hanya sebatas Hak tersangka atau terdakwa terlebih bagi perkara yang memiliki ancaman pidana mati atau ancaman pidana lima belas tahun atau lebih atau bagi mereka yang tidak mampu yang diancam dengan pidana lima tahun atau lebih yang tidak mempunyai penasihat hukum sendiri.

Dengan ketentuan tersebut maka advokat tidak dapat maksimal dalam menjalankan tugas dan kewenangannya dalam proses peradilan pidana. Dimana proses peradilan pidana tidak membedakan bentuk perbuatan ataupun ancaman pidananya. Namun advokat atau disebut sebagai penasehat hukum dalam KUHAP, hanya pada perkara tertentu dalam bentuk Hak. Sehingga tiada suatu kewajiban bagi advokat untuk melaksanakan tugas sebagai penegak hukum sebagaimana disebutkan dalam UndangUndang Nomor 18 Tahun 2003 tentang Advokat.

Disimpulkan bahwa dalam teori penegakan hukum, eksistensi advokat dalam proses peradilan pidana belum maksimal dimana dipengaruhi oleh: 
a) Substansi Hukum

Advokat sebatas hak tersangka dan pada tindak pidana yang diancam dengan pidana mati atau ancaman pidana lima belas tahun atau lebih atau bagi mereka yang tidak mampu yang diancam dengan pidana lima tahun atau lebih yang tidak mempunyai penasihat hukum sendiri.

b) Struktur Hukum

Peran advokat sebagai penegak hukum dalam proses peradilan pidana, mengacu pada struktur hukum di Indonesia maka kinerja sebagai penegak hukum bersifat bebas dimana advokat dalam menjalankan profesinya berdasar pada kontra prestasi dari sang klien. Meskipun tetap wajib dalam menjalankan kegiatannya juga tunduk pada KUHAP.

c) Budaya Hukum

Advokat sebagai penegak hukum, disisi budaya hukum di Indonesia, belum dapat maksimal dimana lebih didominasi peranan aparat penegak hukum yang lebih dikenal oleh masyarakat yaitu Polisi, Jaksa dan Hakim semata.

Oleh karenanya peneliti, memberikan catatan bahwa jika diukur dari teori penegakan hukum, maka eksistensi advokat sebagai penegak hukum belum terlaksana dengan baik.Berikutnya eksistensi advokat sebagai penegak hukum dalam proses peradilan pidana dari kacamata teori dalam sistem peradilan pidana, maka advokat lebih mendominasi untuk dapat ikut masuk ke setiap tahapan. Didalam sistem peradilan pidana, terkandung aspek hukum yang menitikberatkan kepada operasionalisasi peraturan perundang-undangan dalam upaya menanggulangi kejahatan dan bertujuan mencapai kepastian hukum. Advokat dalam hal ini sebagai pihak yang bertugas agar hak dan kewajiban klien dapat berjalan dengan baik termasuk menghindari kesalahan prosedural dalam penanganan perkara. Namun lagi-lagi, tugas dan kewajiban advokat tidak dapat berjalan tanpa adanya kuasa dari klien atau tersangka.

Sistem peradilan pidana yang dianut oleh KUHAP terdiri dari subsistem yang merupakan tahapan proses jalannya penyelesaian perkara, subsistem penyidikan dilaksanakan oleh kepolisian, subsistem penuntutan dilaksanakan oleh kejaksaan, subsistem pemeriksaan di sidang pengadilan dilaksanakan oleh pengadilan, dan subsistem pelaksanaan putusan pengadilan dilaksanakan oleh kejaksaan dan lembaga pemasyarakatan.

Sistem peradilan sebagai bentuk mekanisme penegakan hukum diisi oleh aktoraktor penegak hukum terdiri dari polisi, jaksa, hakim (pengadilan), lembaga pemasyarakatan kemudian advokat. Melalui sistem peradilan diharapkan dapat menghadirkan proses penegakan hukum yang berkeadilan sesuai dengan cita negara hukum. Kita ketahui bahwa tiga dari semua itu (polisi, jaksa \& hakim) adalah bentuk representasi negara dalam sistem peradilan, sedangkan advokat bertindak mewakili masyarakat pencari keadilan dan diposisikan di luar sistem. Polisi, jaksa dan hakim memiliki legitimasi formal dari negara sebagai bentuk konkrit pengamalan trias politika, sedangkan advokat tidak memiliki legitimasi seperti itu.

Legitimasi bagi para advokat tercermin dari kepercayaan masyarakat terhadapnya (legitimasi sosial). Secara historis peran advokat atau penasihat hukum ada seiring 
perkembangan hukum dan masyarakat, hukum akan selalu ada selagi ada masyarakat dan masyarakat memerlukan hukum sekaligus menghendaki penegakan hukum.

Kemudian negara sebagai wujud kekuasaan formal, bersama perangkat dan sistem hukumnya dipercayakan untuk melengkapi hukum yang tadi masih berupa kesadaran dan norma moral sehingga menjadi aturan atau norma hukum yang dapat ditegakkan (enforceable). Sebagaimana kita ketahui bahwa negara modern bercirikan bentuk trias politica negara menjalankan tugasnya.

Sasaran menghadirkan advokat selain untuk memenuhi Pasal 56 KUHAP, juga adalah memberikan bantuan hukum bagi terdakwa serta membantu hakim dalam menemukan kebenaran hukum yang berintikan keadilan. Bantuan hukum itu sendiri di dalam ketentuan umum Undang-Undang Nomor 18 Tahun 2003 tentang Advokat menerangkan bahwa bantuan hukum adalah jasa hukum yang diberikan oleh advokat secara cuma-cuma kepada klien yang tidak mampu.

Kemudian jasa hukum itu sendiri adalah jasa yang diberikan oleh advokat berupa memberikan konsultasi hukum, bantuan hukum, menjalankan kuasa, mewakili, mendampingi, membela dan melakukan tindakan hukum lain untuk kepentingan hukum klien. Semua itu jelas bahwa suatu nilai positif yang memang harus tetap dipertahankan dalam proses penegakan hukum yang hakiki agar tidak terjadi diskriminasi dan penyimpangan-penyimpangan dalam proses penegakan hukum sehingga kebenaran dan keadilan dapat dirasakan oleh masyarakat.

Ditegaskan dalam Undang-Undang Nomor 18 Tahun 2003 tentang Advokat bahwa seorang advokat berstatus sebagai penegak hukum, bebas dan mandiri yang dijamin oleh hukum dan peraturan perundang-undangan. Dalam Pasal 5 Ayat (1) Undang-Undang Nomor 18 Tahun 2003 tentang Advokat, disebutkan bahwa keberadaan advokat berstatus sebagai penegak hukum, bebas dan mandiri yang dijamin oleh hukum dan peraturan perudang-undangan.

Berdasarkan Pasal 5 Ayat (1) Undang-Undang Nomor 18 Tahun 2003 tentang Advokat tersebut, dapat diketahui bahwa advokat telah dijamin keberadaanya oleh hukum dan statusnya sebagai penegak hukum. Lebih lanjut dalam penjelasan Pasal 5 Ayat (1) Undang-Undang Nomor 18 Tahun 2003 tentang Advokat, dijelaskan bahwa yang dimaksud dengan advokat berstatus sebagai penegak hukum adalah advokat sebagai salah satu perangkat dalam proses peradilan yang mempunyai kedudukan yang setara dengan penegak hukum lainnya dalam menegakkan hukum dan keadilan.

Dengan adanya Pasal 5 Ayat (1) Undang-Undang Nomor 18 Tahun 2003 tentang Advokat, dapat terlihat bahwa sejatinya keberadaan advokat sebagai penegak hukum mempunyai peran penting dalam menegakkan hukum khususnya dalam sistem peradilan pidana.

Terkait bantuan hukum terhadap tersangka merupakan hak mendasar atau asasi bagi seseorang yang terkena masalah hukum. Sebab memperoleh bantuan hukum merupakan salah satu bentuk akses terhadap keadilan bagi mereka yang atau berurusan dengan masalah hukum. Memperoleh bantuan hukum juga merupakan salah satu perwujudan dari persamaan di depan hukum.

Selanjutnya mengenai bantuan hukum diatur dalam Pasal 1 Angka 9 UndangUndang Nomor 18 Tahun 2003 tentang Advokat, menyebutkan bahwa: 
Bantuan hukum adalah jasa hukum yang diberikan oleh advokat secara cumacuma kepada klien yang tidak mampu. Undang-undang Nomor 4 Tahun 2004 tentang Kekuasaan Kehakiman. Pasal 37 Undang-undang Nomor 4 Tahun 2004 menyebutkan: Setiap orang yang tersangkut perkara berhak memperoleh bantuan hukum.

Pasal 38 Undang-undang Nomor 4 Tahun 2004 tentang Kekuasaan Kehakiman menegaskan: Perkara pidana seorang tersangka sejak saat dilakukan penangkapan dan/atau penahanan berhak menghubungi dan meminta bantuan advokat.

Menurut peneliti terdapat kesenjangan pada advokat yang disebut sebagai penegak hukum dalam proses peradilan pidana. Hal ini berkaitan dengan Pasal 54 KUHAP yang berbunyi:

Guna kepentingan pembelaan, tersangka atau terdakwa berhak mendapat bantuan hukum dari seorang atau lebih penasihat hukum selama dalam waktu dan pada setiap tingkat pemeriksaan, menurut tatacara yang ditentukan dalam undang-undang ini.

Namun dalam bantuan hukum tersebut, terdapat keterkaitan pengertian penerima bantuan hukum dengan hak tersangka atau terdakwa untuk mendapat bantuan hukum ialah terbatas pada status ekonomi serta dibatasi dengan lama ancaman pidananya. Pasal 56 Ayat (1) KUHAP terlihat jelas bahwa sebenarnya telah terjadi diskriminasi terhadap pemenuhan hak dalam proses peradilan pidana di Indonesia, karena pemenuhan hak mengenai bantuan hukum ini dibatasi, dimana berlaku hanya untuk tersangka yang melakukan tindak pidana yang diancam dengan pidana lebih dari 5 tahun.

Dengan adanya batasan tentang ancaman pidana lebih dari 5 tahun dan tidak mampu dalam Pasal 56 Ayat (1) KUHAP, menyebabkan mereka yang tidak mampu melakukan kejahatan dengan ancaman kurang dari 5 tahun tidak lagi wajib untuk disediakan penasihat hukum.

Hal ini tidak sesuai dengan Undang-Undang Nomor 16 Tahun 2011 tentang Bantuan Hukum, merupakan implementasi negara hukum yang mengakui dan melindungi serta menjamin hak asasi warga negara, yaitu adanya bantuan hukum yang diselenggarakan oleh negara, sebagaimana disebutkan dalam Pasal 1 Angka (1) UndangUndang Nomor 16 Tahun 2011 tentang Bantuan Hukum, menyebutkan bahwa:

Bantuan hukum adalah jasa hukum yang diberikan oleh pemberi bantuan hukum secara cuma-cuma kepada penerima bantuan hukum.

Sehubungan dengan hal tersebut, dikemukakan bahwa program-program untuk memberikan informasi mengenai hak dan kewajiban di dalam hukum dan pentingnya peran pembela di dalam melindungi hak-hak kebebasan fundamental harus selalu digelorakan. Mereka yang miskin atau malang yang tidak dapat diperjuangkan sendiri haknya dibantu dalam memperoleh bantuan hukum secepatnya.

Namun dalam praktiknya, dalam hal bantuan hukum terhadap tersangka, seringkali terjadi diskriminatif dimana jarang ditemukan adanya koordinasi dan dukungan dari aparat penegak hukum seperti polisi, jaksa, hakim dalam memberitahukan hak-hak tersangka yang salah satunya adalah hak memperoleh bantuan hukum.

Hal ini dapat dilihat dari jarangnya permintaan kepada advokat oleh aparat penegak hukum baik polisi maupun jaksa untuk memberikan bantuan hukum ketika ada klien yang tidak mampu secara ekonomi dihadapkan dengan perkara pidana dengan ancaman pidana 5 (lima) tahun lebih. Penyidik lebih suka tersangka tidak didampingi oleh 
penasehat hukum dan hal ini biasanya dibenarkan dengan pernyataan tersangka yang tidak mau didampingi oleh advokat ketika disidik.

Menurut peneliti, dengan adanya Pasal 56 Ayat (1) KUHAP tersebut membatasi advokat dalam menjalankan tugasnya untuk membela hak-hak tersangka, terlebih dalam hal ini tersangka yang tidak mampu sehingga tidak punya uang untuk menggunakan penasehat hukum sendiri. Hal ini juga dibuktikan bahwa hak-hak tersangka pada saat dalam penyidikan tidak disampaikan oleh pihak kepolisian kepada tersangka.

Hal ini dilakukan dengan berbagai alasan atau dalih seperti guna untuk memperlancar proses sehingga terhadap tersangka atau terdakwa dianjurkan untuk tidak menggunakan jasa pengacara, tidak adanya anggaran institusi yang diperuntukan untuk menyediakan jasa pengacara atau bantuan hukum kepada tersangka atau terdakwa, bahkan banyak oknum atau pejabat tertentu yang menganjurkan agar tersangka tidak menggunakan penasehat hukum, dan tersangka dikondisikan sedemikian rupa dengan membuatkannya surat pernyataan tidak bersedia didampingi oleh penasehat hukum, dan tidak sedikit dari kalangan aparat yang beranggapan bahwa dengan adanya pernyataan dari diri tersangka atau terdakwa yang tidak bersedia didampingi penasehat hukum merupakan hak asasi tersangka atau terdakwa sehingga aparat penegak hukum tidak merasa perlu lagi menunaikan kewajibannya untuk menunjuk penasehat hukum bagi tersangka atau terdakwa sebagaimana yang diwajibkan oleh ketentuan dalam Pasal 56 KUHAP.

Sejatinya keberadaan advokat sebagai penegak hukum tidak hanya sebagai upaya untuk melindungi hak pencari keadilan dan sebagai pembela namun juga sebagai bentuk perwakilan masyarakat didalam suatu proses peradilan. Dengan demikian diharapkan keberadaan advokat dapat mencegah atau paling tidak mengurangi kesewenangwenangannya dari aparatur penegak hukum yang lain, khususnya bila berkaitan dengan perkara yang melibatkan orang-orang yang tidak mampu.

Makna yang terkandung dalam peran advokat sebagai seorang pembela, bahwa advokat memiliki tugas untuk membela harkat dan marbatabat manusia didalam sebuah proses peradilan pidana. Termasuk tersangka atau terdakwa. Sehingga untuk itu, sudah menjadi hak seorang tersangka atau terdakwa untuk didampingi oleh seorang advokat. Keberadaan advokat dalam perannya untuk melindungi hak-hak tersangka atau terdakwa untuk tidak diperlakukan diluar kemanusiaan merupakan suatu tugas advokat.

Hakikat bantuan hukum, ialah mewujudkan fungsi yang dijalankan melalui pemberian bantuan hukum yaitu: ${ }^{2}$

a) Dengan adanya bantuan hukum akan terwujud persamaan di hadapan hukum, sebab dalam proses hukum yang fair dan impartial hanya akan terjadi apabila pihak-pihak yang bersengketa memiliki posisi dan kekuatan yang seimbang, terutama dari sisi pengetahuan dan keterampilan hukum.

b) Bantuan hukum memberikan ruang interaksi antara para ahli dan profesi hukum dengan masyarakat umum dimana dalam interaksi tersebut akan menumbuhkan pemahaman dan kesadaran dalam memposisikan suatu aturan hukum yang terdapat pada kehidupan berbangsa dan bernegara.

${ }^{2}$ Frans Hendra Winarta, Hak Konstitusional Fakir Miskin Untuk Memperoleh Bantuan Hukum. Gramedia Pustaka, Jakarta, 2009, hlm. 34. 
c) Adanya bantuan hukum maka dapat menjamin dan memenuhi hak bagi penerima bantuan hukum untuk mendapatkan akses keadilan. Sehingga mewujudkan hak konstitusional segala warga negara sesuai dengan prinsip persamaan kedudukan di dalam hukum melalui peradilan yang efektif, efisien, dan dapat dipertanggungjawabkan.

Berpijak pada hakikat bantuan hukum di atas, maka eksistensi advokat sebagai penegak hukum dalam proses peradilan pidana ditinjau dari Pasal 56 Ayat (1) Kitab Undang-Undang Hukum Acara Pidana dibatasi dimana bantuan hukum tersebut diberikan kepada tersangka yang perbuatannya tersangka yang tidak mampu ancaman pidananya lebih dari 5 (lima) tahun. Sehingga tidak terwujudnya persamaan di hadapan hukum, sebab dalam proses hukum yang fair dan impartial hanya akan terjadi apabila pihak-pihak yang bersengketa memiliki posisi dan kekuatan yang seimbang, terutama dari sisi pengetahuan dan keterampilan hukum.

Apabila dalam bantuan hukum tersebut hanya berlaku kepada tersangka yang perbuatannya diancam pidana lebih dari 5 (lima) tahun, maka hal tersebut tidak menjamin dan tidak memenuhi hak bagi penerima bantuan hukum untuk mendapatkan akses keadilan, dimana mewujudkan hak konstitusional segala warga negara sesuai dengan prinsip persamaan kedudukan di dalam hukum melalui peradilan yang efektif, efisien, dan dapat dipertanggungjawabkan.

Adanya bantuan hukum oleh advokat maka dapat menjamin dan memenuhi hak bagi penerima bantuan hukum untuk mendapatkan akses keadilan. Sehingga mewujudkan hak konstitusional segala warga negara sesuai dengan prinsip persamaan kedudukan di dalam hukum melalui peradilan yang efektif, efisien, dan dapat dipertanggungjawabkan. Namun jika bantuan hukum tersebut diberikan dengan syarat ancaman pidana lebih dari 5 (lima) tahun, maka tidak terwujud hak konstitusional setiap warga negara yang mengalami peristiwa hukum.

Hal tersebut juga berkaitan dengan hak atas peradilan yang jujur dan tidak memihak adalah norma yang dirancag untuk melindungi individu dari pembatasan yang tidak sah dan sewenang-wenang, atau perampasan hak dasar dan kebeasan lainnya.

Hak atas bantuan hukum dibedakan menjadi empat bagian, yaitu: ${ }^{3}$

a) Hak untuk membela diri secara pribadi atau untuk dibantu oleh penasehat hukum menurut pilihannya sendiri;

b) Hak untuk mendapatkan bantuan hukum cuma-cuma dalam hal orang yang tidak mampu membayar jasa advokat demi kepentingan hukum dan keadilan;

c) Hak untuk berkomunikasi dengan advokat;

d) Hak untuk diberitahukan mengenai haknya untuk mendapatkan bantuan hukum.

Terlebih pada saat pemeriksaan pendahuluan, ketentuan KUHAP menganut azas pemeriksaan Inquisitor Lunak artinya bahwa dalam pemeriksaan yang dilakukan oleh penyidik terhadap tersangka boleh didampingi oleh Penasehat Hukum yang mengikuti

\footnotetext{
${ }^{3}$ Agustinus Edy Kristianto, Pedoman Bantuan Hukum Di Indonesia, Yayasan Obor Indonesia, Jakarta, 2009, hlm. 3
} 
jalannya pemeriksaan secara pasif yakni Penasehat hukum diperkenankan untuk melihat, mendengar dan memberikan petunjuk dalam proses pemeriksaan terhadap tersangka.

Dalam praktek, pemeriksaan dalam sistem Inquisitor Lunak ini, tersangka boleh meminta kepada Penasehat Hukum penjelasan-penjelasan tentang maksud dari pertanyaanpertanyaan dari penyidik, terutama terhadap pertanyaan-pertanyaan yang sifatnya menjerat. Tersangka dalam proses pemeriksaan pendahuluan tidak diperlakukan sebagai terdakwa (obyek) yang harus diperiksa, melainkan tersangka dilakukan sebagai subyek, yang artinya tersangka tidak dapat dipaksa untuk mengaku bersalah dengan cara paksaan, tekanan ataupun ancamanancaman. Ketentuan ini jelas terdapat dalam Pasal 52 dan 184 Ayat (1) KUHAP, yang intinya menyatakan bahwa tujuan pemeriksaan pendahuluan oleh penyidik tidak untuk mendapatkan pengakuan tersangka tetapi untuk mendapatkan keterangan tersangka mengenai peristiwa pidana yang dipersangkakan kepadanya.

Terlebih dalam proses pemeriksaan awal, keberadaan advokat bersifat fakultatif artinya hak itu tidak dapat dipaksakan kepada penyidik, semata-mata tergantung kehendak dan pendapat penyidik apakah akan memperbolehkan atau tidak mengikuti jalanya pemeriksaan penyidikan. Pasif dalam arti kehadiran penasehat hukum mengikuti jalannya pemeriksaan hanya melihat dan mendengar isi jalannya pemeriksaan dan sifat pasif ini semakin dibatasi dalam hal kejahatan terhadap keamanan negara yang hanya dapat melihat dan tidak dapat mendengar jalanya pemeriksaan. Hal yang demikian tidak menempatkan kedudukan dan persamaan derajat yang sama antara penyidik dan penasehat hukum.

Berpijak pada teori penegakan hukum yang diketengahkan oleh Lawrence Meir Friedman, dimana menjelaskan penegakan hukum dipengaruhi oleh substansi hukum, struktur hukum dan budaya hukum. Terhadap eksistensi advokat dalam sistem peradilan pidana terlihat dalam Undang-Undang Nomor 18 Tahun 2003 tentang Advokat namun dibatasi dalam menjalankan tugasnya sebagai penegak hukum.

Hal ini dipengaruhi oleh substansi hukumnya dimana Pasal 56 Ayat (1) KUHAP hanya bersifat imperatif, bantuan hukum tersebut diberikan tersangka atau terdakwa yang tidak mampu diduga melakukan tindak pidana yang ancaman pidananya lebih dari 5 tahun.

Selanjutnya, terkait dengan struktur hukum dimana hukum tidak dapat berjalan atau tegak bila tidak ada aparat penegak hukum yang kredibilitas, kompeten dan independen. Seberapa bagusnya suatu peraturan perundang-undangan bila tidak didukung dengan aparat penegak hukum yang baik maka keadilan hanya angan-angan. Dalam hal bantuan hukum terhadap tersangka, jarang ditemukan adanya koordinasi dan dukungan dari aparat penegak hukum seperti polisi, jaksa, hakim dalam memberitahukan hak-hak tersangka yang salah satunya adalah hak memperoleh bantuan hukum.

Hal ini dapat dilihat dari jarangnya permintaan kepada advokat oleh aparat penegak hukum baik polisi maupun jaksa untuk memberikan bantuan hukum ketika ada klien yang tidak mampu secara ekonomi dihadapkan dengan perkara pidana dengan ancaman pidana 5 (lima) tahun lebih. Penyidik lebih suka tersangka tidak didampingi oleh penasehat hukum dan hal ini biasanya dibenarkan dengan pernyataan tersangka yang tidak mau didampingi oleh advokat ketika disidik.

Terkait pengaruh budaya hukum dalam penegakan hukum oleh advokat, dibuktikan dengan kepercayaan masyarakat kepada peran advokat sebagai penegak hukum menjadi pudar. Dominasi penegak hukum polisi, jaksa dan hakim dalam peradilan pidana 
menjadikan adanya fenomena kesewenang-wenangan, arogansi yang kerap dilakukan. Jika berbicara mengenai advokat selalu ada semacam anggapan buruk terhadap profesi tersebut. Disatu pihak advokat dianggap sebagai profesi yang senang mempermainkan hukum dan bikin perkara.

Disisi lain, siapa lagi yang dapat menolong orang yang sedang berpekara didalam persidangan kalau bukan advokat. Kaitan dengan proses peradilan pidana di Indonesia, advokat diberi ruang didalam setiap tahapan mulai dari:

1) Penyidikan

Advokat dapat mendampingi dengan memberikan nasehat hukum serta kontrol atas tindakan-tindakan yang tidak dibenarkan oleh undang-undang.

2) Penuntutan

Advokat berperan dalam menganilis apakah suatu dakwaan itu berkualitas atau sesuai dengan fakta yang dialami oleh tersangka atau terdakwa. Sehingga dapat melakukan eksepsi ataupun sebaliknya advokat dapat membantu agar proses peradilan dapat berjalan lancar dengan memberikan pemahaman terhadap tersangka atau terdakwa dalam memberikan keterangan yang sebenar-benarnya.

3) Persidangan

Advokat dapat menyampaikan fakta pembanding dari sisi tersangka atau terdakwa dengan tujuan agar mejelis hakim dapat memberikan putusan yang seadil-adilnya didalam putusan.

4) Pelaksanaan Putusan

Advokat berperan sebagai pengawal berjalannya putusan pengadilan dapat berjalan sebagaimana mestinya. Khususnya pada putusan yang bersifat perintah kepada pihak yang terkait dalam perkara.

Maka dapat dikatakan bahwa eksistensi advokat sebagai penegak hukum dalam proses peradilan pidana ditinjau dari Pasal 56 KUHAP, maka advokat mampu sebagai penegak hukum berdasar surat kuasa klien semata dan penunjukan oleh penyidik manakala terdapat perkara yang memenuhi kriteria sebagaimana yang disebutkan dalam Pasal 56 KUHAP.

Disamping itu eksistensi advokat sebagai penegak hukum dalam proses peradilan pidana ditinjau dari Pasal 56 KUHAP terbatas pada ancaman pidana dalam suatu tindak pidana dan tergantung pada pemahaman hukum yang dimiliki penyidik dalam memberikan hak seutuhnya kepada tersangka sejak awal dimulainya proses pemeriksaan. Sehingga eksistensi advokat sebagai penegak hukum akan berpengaruh dalam proses peradilan yang dibatasi oleh bentuk tindak pidana dan ancaman pidana serta subjek pada setiap tingkatan pemeriksaan.

Peneliti dapat memberikan pandangan atas realita tersebut harus dihilangkan, sebab idealitas proses peradilan pidana yang diusung oleh KUHAP ialah kebenaran meteriil sehingga harus didukung dengan kebenaran formil yang menjadi keniscayaan berhasilnya proses peradilan pidana yang sehat, bersih dan mencapai tujuan yaitu kemanfaatan hukum itu sendiri bagi masyarakat. 


\section{B. Implikasi Dari Pasal 56 Kitab Undang-Undang Hukum Acara Pidana Terhadap Eksistensi Advokat Sebagai Penegak Hukum Dalam Proses Peradilan Pidana}

Keberadaan advokat sebagai seorang penegak hukum sejatinya telah diatur didalam Pasal 5 Undang-undang 18 Tahun 2003 tentang Advokat, tatkala ditinjau Dari Pasal 56 Kitab Undang-Undang Hukum Acara Pidana yang mempengaruhi eksistensi advokat sebagai penegak hukum dalam proses peradilan pidana. Dalam menyelenggarakan sistem peradilan pidana, di Indonesia terdapat Undang-Undang Nomor 8 Tahun 1981 tentang Kitab Undang-Undang Hukum Acara Pidana (KUHAP), sebagai hukum acara pidana yang berisi ketentuan mengenai proses penyelesaian perkara pidana sekaligus menjamin hak asasi tersangka atau terdakwa.

Adapun keberadaan Pasal 5 Ayat (1) Undang-undang 18 Tahun 2003 tentang Advokat, yang belum secara konkrit menjelaskan mengenai advokat sebagai penegak hukum menjadi menarik untuk dikaji terlebih atas adanya pendapat-pendapat yang masih meragukan keberadaan advokat sebagai penegak hukum khusunya dalam perannya ia didalam sistem peradilan pidana. Berdasarkan hasil tanya jawab peneliti terhadap rekanrekan penyidik khususnya yang menangani tindak pidana umum, maka terdapat beberapa hal terkait persepsi eksistensi advokat ditengah proses peradilan pidana.

Sebagaimana diketahui proses peradilan pidana diawali adanya penyidikan selanjutnya penuntutan kemudian pemeriksaan di pengadilan hingga terbit produk hukum yaitu vonis mejelis hakim. Hal ini terdapat pada penjelasan bahwa KUHAP sebagai hukum acara pidana yang berisi ketentuan tata tertib proses penyelesaian penanganan kasus tindak pidana, sekaligus telah memberi legalisasi hak asasi kepada tersangka atau terdakwa untuk membela kepentingannya didepan pemeriksaan aparat penegak hukum.

Terkait advokat sebagai penegak hukum dalam proses peradilan pidana, bertugas memberikan jasa hukum terhadap tersangka atau terdakwa. Terlebih bagi tersangka atau terdakwa yang kurang mampu, maka diberikan bantuan hukum dalam setiap proses peradilan yang ia hadapi. Hal ini terkait dengan ketentuan pada Pasal 54 KUHAP, yang menyebutkan bahwa:

Guna kepentingan pembelaan, tersangka atau terdakwa berhak mendapat bantuan hukum dari seorang atau lebih penasihat hukum selama dalam waktu dan pada setiap tingkat pemeriksaan, menurut tatacara yang ditentukan dalam undangundang ini.

Namun, bantuan hukum tersebut hanya diberikan oleh negara kepada tersangka dengan yang melakukan tindak pidana yang ancaman pidananya lebih dari 5 (lima) tahun.

Hal itu diatur dalam Pasal 56 Ayat (1) KUHAP, yang menyebutkan bahwa:

Dalam hal tersangka atau terdakwa disangka atau didakwa melakukan tindak pidana yang diancam dengan pidana mati atau ancaman pidana lima belas tahun atau lebih atau bagi mereka yang tidak mampu yang diancam dengan pidana lima tahun atau lebih yang tidak mempunyai penasihat hukum sendiri, pejabat yang bersangkutan pada semua tingkat pemeriksaan dalam proses peradilan wajib menunjuk penasihat hukum bagi mereka. 
Pemahaman dari Pasal 56 KUHAP yang di dalamnya menegaskan tentang hak dari tersangka atau terdakwa untuk didampingi penasehat hukum apabila tindak pidana yang disangkakan atau didakwakan diancam dengan pidana mati atau ancaman pidana 15 (lima belas) tahun atau lebih, atau bagi yang tidak mampu yang diancam pidana 5 (lima) tahun atau lebih yang tidak mempunyai penasehat hukum sendiri, dimana pejabat yang bersangkutan dalam proses peradilan wajib menunjuk penasehat hukum bagi mereka.

Tujuan pokok yang ingin dicapai atas penegakan hukum dalam proses peradilan seperti yang dimaksud dalam Pasal 56 KUHAP adalah agar terjamin pemeriksaan yang fair dan manusiawi terhadap diri tersangka atau terdakwa, sebab dengan hadirnya penasehat hukum mendampingi tersangka sejak dari proses penyidikan di tingkat kepolisian dimaksudkan dapat berperan melakukan kontrol, sehingga pemeriksaan terhadap diri tersangka terhindar dari penyiksaan, pemaksaan dan kekejaman.

Berpijak pada teori sistem peradilan pidana yang diperkenalkan oleh Herbet Packer dimana terdapat model due process model, yaitu menekankan pada fakta dari suatu kasus yang diperoleh melalui prosedur formal yang sudah ditetapkan oleh undang-undang. Prosedur itu penting dan tidak boleh diabaikan, melalui suatu tahapan pemeriksaan yang ketat mulai dari penyidikan, penangkapan, penahanan hingga peradilan. Maka dalam mencapai terwujudnya due process model, advokat memiliki peran penting dimana advokat dapat masuk dari awal proses peradilan.

Dalam penyidikan, advokat berperan memberikan dukungan moril dan pengetahuan terhadap tersangka yang mana sering dijadikan objek pemeriksaan bukan subjek pemeriksaan. Hal ini sangat penting dimana demi mencapai keadilan materiil yang diusung oleh KUHAP, maka disetiap tahapan pemeriksaan tersangka wajib tertib administrasi peradilan dari proses pemanggilan tersangka hingga penjatuhan putusan oleh majelis hakim. Peneliti sependapat dengan apa yang disampaikan oleh Satjipto Rahardjo menjelaskan bahwa peranan advokat dalam pengadilan ialah sebagai penjaga (pengawal) kekuasaan pengadilan. Dalam hal ini advokat mengawal agar para penegak hukum yang lain tidak melakukan penyelewengan-penyelewengan sehingga tidak merugikan hak tersangka ataupun terdakwa.

Dapat dilihat bahwa adanya pembatasan kewenangan advokat dalam memberikan bantuan hukum terhadap tersangka yang tidak mampu. Sehingga berakibat pada eksistensi advokat sebagai penegak hukum dalam proses peradilan pidana. Kewenangan advokat sebagai pembela hak-hak tersangka hanya sebagai formalitas saja, namun dalam praktiknya advokat dalam tugasnya dibatasi oleh Pasal 56 Ayat (1) KUHAP tersebut.

Fakta yang tidak terbantahkan bahwa keberadaan advokat sangat dibutuhkan oleh masyarakat, khususnya masyarakat yang tersandung perkara hukum, untuk menunjang eksistensi advokat dalam menjalankan fungsi dan tugasnya dalam sistem penegakan hukum, maka diperlukan kewenangan yang harus diberikan kepada advokat. Kewenangan advokat tersebut diperlukan dalam rangka menghindari tindakan kesewenangwenangan yang dilakukan oleh aparat penegak hukum yang lain (Hakim, Jaksa, Polisi) dan juga dapat memberikan batasan kewenangan yang jelas terhadap advokat dalam menjalankan profesinya. Dalam praktik seringkali keberadaan advokat dalam menjalankan profesinya seringkali diabaikan oleh aparat penegak hukum. Hal ini mengakibatkan kedudukan advokat tidak sejajar dengan aparat penegak hukum yang lain. 
Seorang advokat adalah seorang yang berprofesi memberi jasa hukum, baik didalam maupun diluar pengadilan yang memenuhi persyaratan sebagaimana tercantum dalam ketentuan Undang-Undang Nomor 18 Tahun 2003 tentang Advokat. Makna kehadiran Undang-Undang Advokat tersebut ditegaskan bahwa seorang advokat berstatus sebagai penegak hukum, bebas dan mandiri yang dijamin oleh hukum dan peraturan perundang-undangan.

Kewenangan Advokat dari segi kekuasaan yudisial advokat dalam sistem kekuasaan yudisial ditempatkan untuk menjaga dan mewakili masyarakat. Sedangkan hakim, jaksa, dan polisi ditempatkan untuk mewakili kepentingan negara. Pada posisi seperti ini kedudukan, fungsi dan peran advokat sangat penting, terutama di dalam menjaga keseimbangan diantara kepentingan negara dan masyarakat. Ada dua fungsi Advokat terhadap keadilan yang perlu mendapat perhatian yaitu:

Pertama kepentingan, mewakili klien untuk menegakkan keadilan, dan peran advokat penting bagi klien yang diwakilinya. Kedua, membantu klien, seseorang Advokat mempertahankan legitimasi sistem peradilan dan fungsi Advokat. Selain kedua fungsi Advokat tersebut yang tidak kalah pentingnya, yaitu bagaimana Advokat dapat memberikan pencerahan di bidang hukum di masyarakat.

Peneliti dapat memberikan pandangan terhadap eksistensi advokat dalam menjalankan fungsi dan tugasnya diberikan kewenangan dalam statusnya sebagai aparat penegak hukum, maka kedudukannya sejajar dengan aparat penegak hukum yang lain. Sehingga dengan kesejajaran tersebut akan tercipta keseimbangan dalam rangka menciptakan sistem penegakan hukum yang lebih baik.

Maka tiba saatnya peneliti memberikan pandangan terkait dengan implikasi dari Pasal 56 KUHAP terhadap eksistensi advokat sebagai penegak hukum dalam proses peradilan pidana, ketentuan adanya kriteria pemberdayagunaan fungsi advokat maka kehadirannya tergantung pada kondisi perkara.

Mengurai pada ketentuan Pasal 56 KUHAP maka tidak sejalan dengan apa yang diamanatkan oleh Konstitusi negara yaitu equality before the law yang peneliti maknai persamaan dalam mengakses keadilan dengan pranata hukum yang telah disediakan.

Advokat sebagai sarana dalam mewujudkan kemudahan akses menuju keadilan dibatasi oleh ketentuan-ketentuan atau formalitas undang-undang. Maka ini berimplikasi terhadap eksistensi advokat dalam menjalankan peranannya ditengah proses penegakan hukum, yang ironinya disebut sebagai penegak hukum namun tidak berdaya karena adanya pembatasan manakala terdapat tersangka atau terdakwa yang tidak mampu diduga melakukan tindak pidana yang ancaman pidananya lebih dari 5 tahun dan ketika melakukan tindak pidana yang ancaman pidananya 15 tahun atau lebih atau ancaman hukuman mati.

Selain hal tersebut diatas terdapat implikasi diluar pranata hukum, yaitu akibat pola yang ada maka advokat mesti jemput bola (klien) dengan segala macam cara yang dilakukan. Hal ini mencederai marwah profesi terhormat yang melekat pada diri seorang advokat. Sebagai profesi yang elegan, advokat dituntut untuk dapat bekerja secara professional, terikat pada etika profesi dan tanggung jawab standar keilmuan. Citra advokat sebagai profesi yang anggun akan ditentukan oleh etos profesi dalam arti sejauh 
mana komunitas advokat sanggup menerapkan standar etika serta keterampilan teknik berprofesi.

\section{PENUTUP}

Berdasarkan pembahasan dan analisis dalam penelitian ini maka peneliti dapat memberikan kesimpulan sebagai berikut:

1. Eksistensi advokat sebagai penegak hukum dalam proses peradilan pidana ditinjau dari Pasal 56 KUHAP terbatas pada ancaman pidana dalam suatu tindak pidana dan tergantung pada pemahaman hukum yang dimiliki penyidik dalam memberikan hak seutuhnya kepada tersangka sejak awal dimulainya proses pemeriksaan. Sehingga eksistensi advokat sebagai penegak hukum akan berpengaruh dalam proses peradilan yang dibatasi oleh bentuk tindak pidana dan ancaman pidana serta subjek pada setiap tingkatan pemeriksaan.

2. Implikasi Pasal 56 Kitab Undang-Undang Hukum Acara Pidana terhadap eksistensi advokat sebagai penegak hukum dalam proses peradilan pidana adalah terbatasinya peran advokat dalam proses peradilan, sehingga tidak dapat hadir pada setiap perkara pidana dan peran advokat tidak dilibatkan sejak awal dimulainya proses peradilan sehingga mengakibatkan tumbuhnya praktek bina jaringan guna mendapatkan peran dalam suatu proses peradilan pidana yang dapat mencederai makna officium nobile yang melekat pada diri seorang advokat.

\section{REFERENSI}

Agustinus Edy Kristianto, Pedoman Bantuan Hukum Di Indonesia, Yayasan Obor Indonesia, Jakarta, 2009

Abdulkadir Muhammad, Etika Profesi Hukum, cetakan ke-3, Citra Aditya Bhakti, Bandung, 2006

Muladi, Kapita Selekta Sistem Peradilan Pidana, Penerbit Undip, Semarang, 1998.

Frans Hendra Winarta, Hak Konstitusional Fakir Miskin Untuk Memperoleh Bantuan Hukum.

Gramedia Pustaka, Jakarta, 2009.

Undang-undang Dasar Negara Republik Indonesia Tahun 1945;

Undang-undang Nomor 1 Tahun 1946 tentang Peraturan Hukum Pidana;

Undang-undang Nomor 8 Tahun 1981 tentang Hukum Acara Pidana;

Undang-undang Nomor 2 Tahun 2002 tentang Kepolisian Negara Republik Indonesia;

Undang-undang Nomor 18 Tahun 2003 tentang Advokat; 